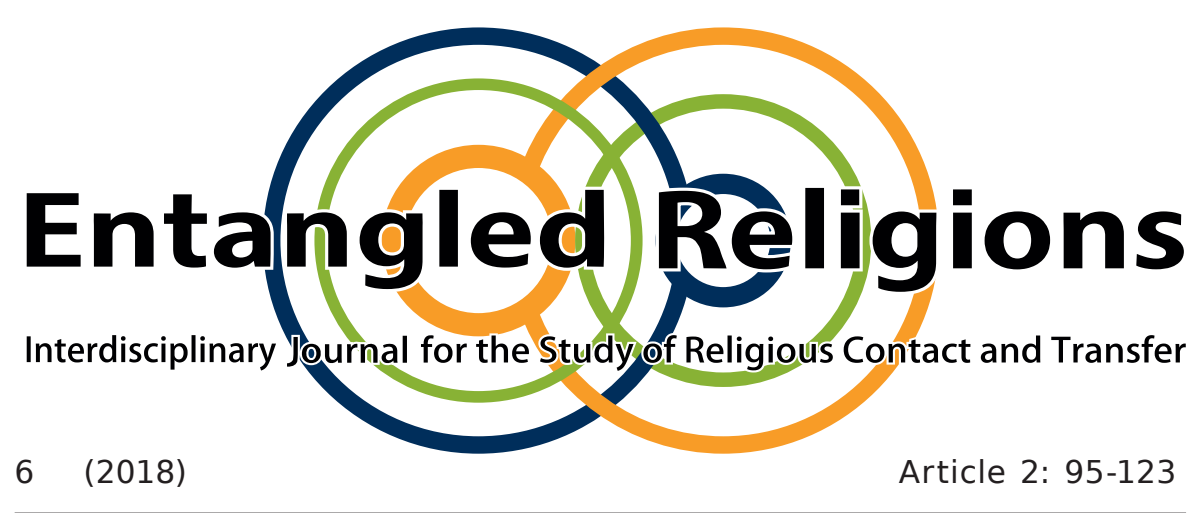

\title{
"Oil, which shall not quit my head": Jewish-Christian Interaction in Eleventh-century Baghdad
}

YOSAIF M DUBOVICK

Achva Academic College and Ben Gurion University of the Negev, Israel

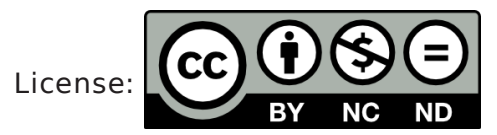

This contribution to Entangled Religions is published under the Creative Commons Attribution-NonCommercial-NoDerivatives 4.0 International Public License (CC BY-NC-ND 4.0 International). The license can be accessed at http://creativecommons.org/licenses/ by-nc-nd/4.0/ or is available from Creative Commons, 559 Nathan Abbot Way, Stanford, California 94305, USA

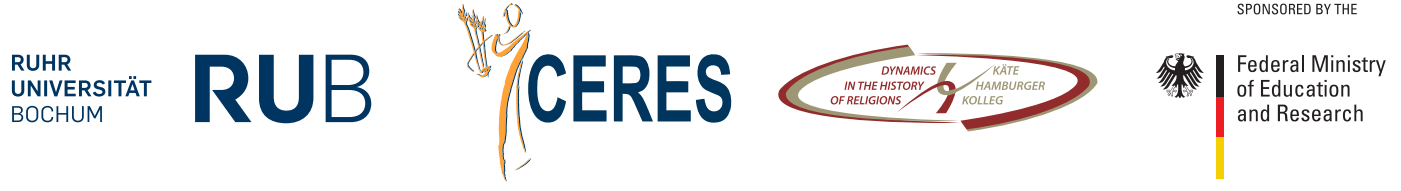




\title{
"Oil, which shall not quit my head": Jewish-Christian Interaction in Eleventh-century Baghdad
}

\author{
YOSAIF M DUBOVICK
}

Achva Academic College and Ben Gurion University of the Negev, Israel

\begin{abstract}
The last influential head of the Pumbadithan Academy in Baghdad, R. Hayya Ga'on (939-1038), requested his Sicilian student R. Mașliah ben Eliah al-Bașaq to inquire with the Nestorian Patriarch (Catholicos) about the Syriac definition of a word in Psalms (141:5). Upon R. Mașliah's protests, R. Hayya rebuked his student, saying “our pious forefathers and ancestors would inquire regarding languages and their explanations from members of different religions, even from shepherds". Despite scholarly treatment since 1855, a new, analytical reading of the text, based upon manuscripts, external sources, and comparative literature, provides fresh approaches towards understanding Jewish-Christian scholarly interaction in Baghdad at the turn of the eleventh century, particularly in comparison to those in Sicily. Additionally presented are new facets in Peshitta studies.
\end{abstract}

KEY WORDS R. Hayya Ga’on; R. Mașliaḥ ben Eliah of Sicily; Geonic Literature; Jewish-

Christian interaction; Nestorian Patriarch (Catholicos); Targum; Syriac; Peshitta

\section{Introduction}

Sometime in the beginning of the eleventh century, a curious episode transpired between two religious leaders in Baghdad, one Jewish and one Christian. Namely, the Jewish leader R. Hayya requested Bible commentary from an unnamed Nestorian Patriarch. Since its excerpted publication in 1855 from a manuscript of a commentary to Song of Songs in Judeo-Arabic by R. Yosef ben Yehuda ibn 'Aqnin (Steinschneider 1855, 57), followed by a 
full publication in 1964 of ibn 'Aqnin's commentary (Halkin 1964, 494-495), the episode has drawn attention to R. Hayya's willingness to avail himself of Christian commentary.

However, despite tens of citations of the episode, all citations refer back to the same original publications, which are based upon the reading in a single manuscript (in Judeo-Arabic), Oxford Pocock 189 in the Bodleian Library (Neubauer 356). Abraham Halkin (1964), too, based his edition on the Oxford manuscript and provided a critical apparatus to his edition based on a parallel (fragmentary) manuscript in the Jewish Theological Seminary library, Lutzki 1056 (EMC 155). However, a critical analysis of the two witnesses has yet to be done. Current research is still based solely upon the Oxford manuscript readings, with only two scholars mentioning the variant readings from the JTS manuscript (Greenbaum 1978, 317; Gil 2004, 591, citing Greenbaum).

A critical comparison of the Judeo-Arabic text in the two manuscripts reveals that the JTS manuscript is superior to the Oxford manuscript, providing a more accurate reading. Therefore it should be used as the base text, rather than the Oxford manuscript (although it should be noted that the JTS manuscript is not without its own errata). In the following pages, I present a new reading of the text, followed by an in-depth analysis of the episode as well as cross-references to parallel sources (one of which is still unpublished). Additionally, since the account revolves around a Biblical verse, the verse and its commentary will be discussed in an attempt to provide both a historical background and a literary perspective for the episode. Following this, I offer a re-evaluation of the cultural background of the characters involved in the incident.

Finally, it should be stressed that a good deal of the topics related to this episode and touched upon in this article has yet to be thoroughly 
researched. Firstly, a critical edition of R. Hayya's Judeo-Arabic dictionary, which would have provided a safer ground for philological analysis, is still a desideratum. Secondly, we have scanty information regarding the Jewish usage of the Peshitta (Syriac Bible tradition). ${ }^{1}$ Thirdly, there is still no conclusive research regarding the date and the location of the composition of the Jewish Aramaic translation of Psalms, its transmission, and its acceptance. And, fourthly, very little is known about the Jewish community in Sicily in the eleventh century. Thus, while in many ways this article is programmatic, posing questions to be answered by future research, it provides a textual and intertextual analysis that may in turn point at venues for further studies on the above-mentioned topics.

\section{Ibn 'Aqnin's Text (based on JTS Lutzki 1056): Retelling of the Anecdotal Encounter}

R. Yosef ben Yehuda ibn 'Aqnin, a thirteenth-century Spanish-born North African scholar, composed a Judeo-Arabic commentary to the Biblical book Song of Songs: Inkishāf al-asrār wa-ẓuhūr al-anwār (אנכשאף אלאסראר וטהור) (אלאנואר), or "Divulging of Secrets and Appearance of Lights". In his concluding essay, ibn 'Aqnin elaborates upon the permissibility of utilizing non-Jewish sources as commentary and proof-texts. One of his sources in his argument is the following anecdote, which transpired close to two centuries prior (Halkin 1964, 494-495). R. Hayya (939-1038), the last influential Ga'on (head) of the Pumbadithan Academy (Yeshiva) in Baghdad, sent his Sicilian student R. Mașliaḥ ben Eliah al-Bașaq to ask the Nestorian

1 The Peshitta is the standard version of the Bible used in Syriac Christian churches, supposedly translated from Hebrew to Syriac (a dialect of Eastern Aramaic). 
Patriarch (Catholicos) what his tradition of a phrase in Psalms (141:5) was. Upon R. Mașliah's protests to the mission, R. Hayya rebuked his student, saying "our pious forefathers and ancestors would inquire regarding languages and their explanations from members of different religions, even from shepherds and cow-hands".

This incident is evidence of Jewish and Christian scholars interacting in Baghdad at the turn of the eleventh century. It was first brought to the attention of scholars by Moritz Steinschneider in 1855 as a historical fact regarding R. Mașliah's life and history $(1855,57)$. Since then, this anecdote has been offered in every scholarly mention of R. Mașliaḥ (for a summary of the references, see Gil 2004, 591; Simonsohn 2011, 71-72). Furthermore, as is to be expected from its relevance to R. Hayya's biography, the incident has been noted by scholars who discussed his life or, alternately, his reliance on non-Jewish sources in his writings (Sklare 1996, 74; Brody 1998, 301; Maman 2000, 353-354, 368-369). Additionally, this account has been utilized in Bible studies (Leonhard 2001, 160; Carbajosa 2008, 267-268) as well as in an attempt to date Aramaic Bible traditions (Weitzman 1999, 74, 209). The episode, as told by R. Yosef ibn 'Aqnin, is as follows:

The Nagid (R. Samuel ibn Nagrilah), may his soul rest in Paradise, recounted with this in his work The Book of Contentment, after having cited at length Christian commentaries, how R. Mașliaḥ ben al-Bașaq, Dayan (judge) of Sicily, wrote him upon his return from Baghdad, an epistle in which he included the demeanor of R. Hayya Ga'on of blessed memory and his meritorious traits, and recounted among other things how one day in the gathering the verse šemen roš 'al yani roši (שמן ראש אל יני ראשי) was mentioned and the attendees disagreed over its interpretation. R. Hayya bade R. Mașliah to go to the Christian Catholicos to ask him what commentarial traditions he has for this verse. This was odious to him ( $R$. 
Mașliah). He (R. Hayya Ga'on) of blessed memory, upon seeing how distressing the behest was for R. Mașliah, the Ga'on of blessed memory reproached him saying "our pious forefathers and ancestors who are our paragons would inquire regarding languages and their explanations from members of different religions, even from shepherds and cow-hands, as is well known and passed down". He (R. Mașliaḥ) arose and went to him (the Patriarch) and asked him. He (the Patriarch) told him (R. Mașliaḥ) that their [tradition] in Syriac was mšḥa d-ršya'a la 'ady ryšyh ("oil of the wicked shall

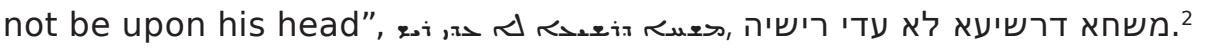

Before presenting an analysis of the text, it is incumbent to point out that the information provided in this account is secondary, if not possibly tertiary. Ibn 'Aqnin clearly states that R. Mașliah, a principal figure in the event, later transmitted what transpired to R. Samuel ibn Nagrilah, the Nagid (communal leader), in Grenada. R. Samuel quotes this account in his own work, Kitāb al-istighnā' (the Book of Contentment) ${ }^{3}$, which in

2 The English text above is a translation from the following Judeo-Arabic original, based primarily on Ms. JTS Lutzki 1056, with variant readings from Ms. Oxford Poc. 189 (Neubauer 356). I am indebted to Prof. Mordechai Akiva Friedman for his invaluable assistance in determining the primacy of Ms. Lutzki 1056 and editing the text and translation. Needless to say, any errors rest with the author alone. The Patriarch's quote is per Ms. Oxford Poc. 189. JTS Lutzki 1056 has a slightly different reading which is discussed below.

וד׳כר אלנגיד נ“ע פי כתאב אלאסתגנא מע הד׳א ענד מא אכת'ר מן ד׳כר שרוחאת אלנצארי אן ר' מצליח

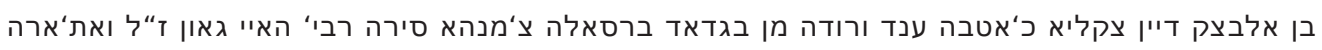

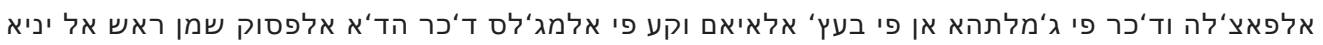

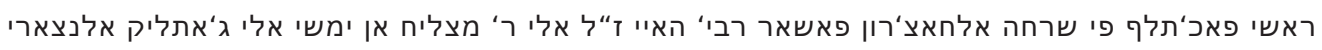

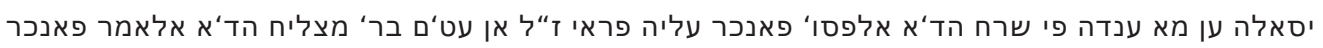

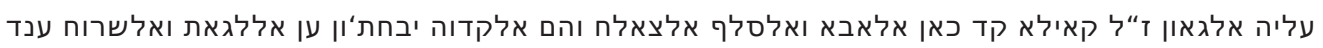

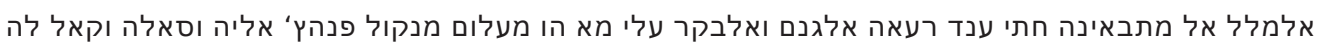

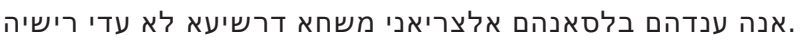

3 The work has not survived intact and to date only fragments of it and quotations from it found in other works have survived. From these scanty sources, it is apparent that the work was a Biblical lexicon, encompassing a broad range of material, its entries having 
turn served as ibn 'Aqnin's source, according to the latter. Additionally, R. Mașliah is mentioned with the epitaph ' $z$ "I', an acronym for zikrono li-braka, "of blessed memory". This blessing is usually reserved for the dead, and is therefore obviously not a part of R. Mașliah's original re-telling of the account. Further, R. Mașliaḥ (died circa 1061) outlived the Nagid (died circa 1056) by more than five years; it is thus almost certain that this blessing cannot be the handiwork of the Nagid either, but rather of ibn 'Aqnin himself. This minor piece of evidence of editing by ibn 'Aqnin suggests that further emendations in the retelling might exist as well. Thus, while from a broad perspective we can safely assume we are reading R. Mașliaḥ's transmission of the episode as preserved by the Nagid and then quoted by ibn 'Aqnin, a measure of caution is still required before attempting to draw conclusions based strictly upon the text as before us.

The first point in our analysis is the setting in which this incident took place. The Judeo-Arabic text defines it by the Arabic term majlis. Though this Arabic word most commonly means "gathering" or "assembly", in this context it seems fairly clear that the intended Hebrew translation of the original Judeo-Arabic should be Yeshiva, the Hebrew term commonly denoting a Rabbinic Academy (Sklare 1996, 100; Blau 2006, 92). Additionally, it seems most logical that had the setting been an interfaith gathering for the purpose of debate, as was common in Baghdad at the time (and also known as majlis, see below), the Sicilian R. Maṣliah would have protested against participation in such a venue to begin with. The implication of defining majlis as Yeshiva is that the discussion arose between the students and the Master within the confines of R. Hayya's Academy in Baghdad. The setting is then to be viewed as a closed one, an internal debate between the

been arranged by root in alphabetical order. From the fragmentary evidence, it is clear that the Nagid made frequent comparisons, lexicographical as well as grammatical, to Arabic cognates (Eldar 2014, 70-71). 
Academy's faculty and students over a Biblical lexeme, perhaps philological (see below), although we cannot completely rule out the possibility that the debate started as an outgrowth of studying some unmentioned Rabbinic text.

This episode is echoed in another, almost identical episode related in an anonymous Judeo-Arabic commentary to Psalms 103:5 (Harkavy 1970, 113; Ben Sasson, 1991, 137). Here, too, R. Samuel the Nagid is quoted, recounting how R. Mașliah transmitted to him how he was present before R. Hayya Ga'on when a discussion arose regarding a verse in Psalms. However, in this account R. Hayya Ga'on settled the argument by citing a work of his own, his Compendium (see below), to weigh in on the correct definition.

While this second incident of Bible exegesis/philology within the Academy was eventually resolved internally, it seems R. Hayya Ga'on deemed our question required outside expertise. The contrast in sending a Talmud scholar to inquire after a definition from the highest Christian authority in the East for the purpose of settling an internal dispute is indeed quite striking, especially when compared to a very similar account.

\section{Psalms 141:5 and its Jewish and Syriac Christian translation traditions}

The next step in our analysis is the subject of the debate. The account as

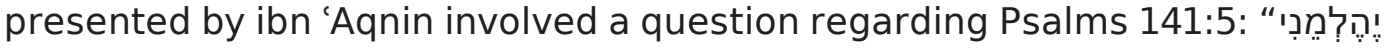

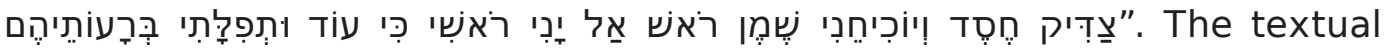
difficulties posed by the entire verse become evident when translating it. One translation reads: "Let the righteous man strike me in loyalty, let him reprove me; let my head not refuse such choice oil. My prayers are still 
against their evil deeds" (JPS 1985, 1276). Ignacio Carbajosa renders the verse thus: "The righteous one will strike me [with?] mercy and will rebuke me; the oil of the head my head will not reject [?], because still [?] and my prayer against their wicked-deeds" (2008, 262). Indeed, modern commentators have expressed their uncertainty in translation regarding this verse (JPS 1985, 1276; Berlin and Brettler 2004, 1439), some pointing to the unclear syntactic function and correct interpretation of the noun "חסד" (hesed; "mercy"? or "loyalty"?-Is it a direct object of the verb, or is it a modifier of the noun preceding it? Does it mean mercy or otherwise loyalty?). Additionally noted is the difficult construction "כי עוד ותפלתי" (ki 'od u-təfilati, literally "because still and my prayer"?). Ignacio Carbajosa $(2008,263)$ notes that the Peshitta omits the adverb ("still") to create the phrase "because my prayer". The Medieval French commentator Rashi reads the phrase as "for as long as my prayer", as if the text read "כל כל "רon עוד". It should be noted that the noun שמן ראשי, "head oil", "choice oil", or "anointing oil" (see below) is also not clear, as evidenced by the various suggested translations above.

Our text clearly states that the dispute arose over the explanation of the phrase šemen roš 'al yani roši, the question focusing almost certainly upon the definition of the verb yani. This verb had already been the subject of debate by early exegetes. Menahem ben Jacob ben Sruq (circa 910 circa 970; Filipowski 1854, 121; Stern 1870, 88) is cited as having explained this verb to mean "to break". His literary opponent and critic Dunaš ben Labrat (circa 925 - circa 990) saw this verb as "to deny" or "to withhold" (Filipowski 1855, 21). Dunaš's opinion most likely originated from his Master, the great exegete, lexicographer, and halakhist R. Saadyah Ga'on, who, in his Tafsir Tehillim (Judeo-Arabic translation and commentary to Psalms), translated this verse in this very fashion (Kafih 1966, 278). Before his death in 942, R. Saadyah had served as Ga'on of the rival Suran 
Academy in Baghdad, and while his literary works were composed close to a century prior to our episode, the close proximity of the two Academies as well as the popularity his works enjoyed allow us to posit that his position in this debate was at the very least known within the rival Pumbadithan Academy, even at such a late date. Further, we make note that the Aramaic Targum (translation tradition) to Psalms also sees the definition of the verb yani as "to cease", "to quit", or "to withhold" (משח רבות קודשא לא יבטל מן ריש, mašaḥ rabot qodša' lo yibțal min roši, "sacred anointing oil shall not be withheld from my head"). While there is yet to be offered sufficient external evidence that this Targum was known in Baghdad at the time (Weitzman 1999, 208-209; Stec 2004, 1-2), its usage of the same tradition as the above exegetes is quite telling as to the popularity of the tradition. Additionally, the tradition "to quit" or "to withhold" was well-known among Karaite (Jews who do not accept the Rabbinic law as binding) exegetes as well, such as the North African-born Jerusalemite David ben Abraham Alfasi (circa 950) in his dictionary of Biblical lexemes, Kitāb Jāmi‘ al-alfāẓ (Skoss 1936, 7; Skoss 1945, 244-245), and his contemporary Yefet ben 'Ali (circa 900 - circa 980) in his commentary to Psalms, translating the problematic verse as follows (Ms Copenhagen 3): “choice oil should not be withheld from my head" (ודהן, wלמאתפע לא ימנע ען ראסי wa-dahan al-mātfa' la yimna' 'an rāsi). Thus, it seems highly likely that the same argument had been posed among the Yeshiva's students.

The debate changes the phrase from "anointing oil which shall not quit my head" to "[as] anointing oil [and thus] will not break my head". Either way, both views see this stich as reflective of the verse's previous one, "blows from the Righteous"|"the Righteous will strike me". 


\section{The Syriac Traditions}

To better appreciate R. Hayya's usage of the Syriac tradition, it is important to compare the Patriarch's tradition with the known Peshitta text witnesses and then compare those findings with the Masoretic text.

The Patriarch's Syriac translation (as witnessed in Ms. Oxford Poc. 189, see below): mšḥa d-ryšy'a lo 'ady rešeh ("the oil of the wicked shall not be upon his head") includes several important shifts from the Masoretic text. First, the Patriarch's tradition reads šemen roš ("head oil”, fig. "anointing oil") as mšha d-ryš'a, "oil of the wicked". This is concurrent with the majority

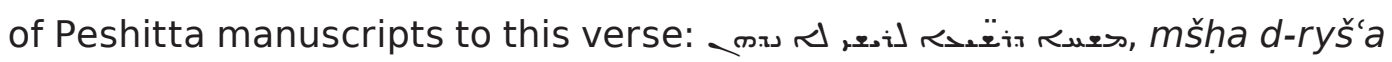
Iryšy la ndhn ("oil of the wicked will not anoint my head"), and is in line with the Septuagint's reading of the verse, too (Carbajosa 2008, 263). Second, both the Patriarch's tradition as well as the common Peshitta version see this stich as independent of the previous one ("blows from the Righteous"). Most important is the fact that both the Patriarch's tradition as well as the Peshitta replace the verb yani with another verb; the Patriarch has 'ady, which can be translated as "pass over" or "be upon", while the Peshitta reads ndhn, "anoint" (Leonhard 2001, 160; Carbajosa 2008, 263).

Although there is no mention of this in ibn 'Aqnin's account, it seems peculiar that upon hearing the Patriarch's reply R. Hayya Ga'on offered no comment. The very cause for asking for the Patriarch's tradition, a definition of the verb yani, is sorely lacking in the response and thus ostensibly of little or no value to R. Hayya Ga'on's and the Academy's debate. Moreover, since the Christian tradition reads "oil of the wicked" in place of the Masoretic "anointing oil", one would expect R. Hayya Ga'on to have voiced a comment to that effect.

It may be suggested that R. Hayya Ga'on did indeed comment after the fact, and perhaps R. Maṣliaḥ even mentioned this in his recount. However, 
due to the nature of the citation's contextual use, i.e. the justification of using external sources, perhaps the Nagid or even ibn 'Aqnin truncated that part of the anecdote, as it does not serve their purposes. An unpublished Genizah fragment of R. Hayya Ga'on's own work, presented below, might weigh in on this question. However, before turning our focus to this source and its contribution to the account a few final words regarding ibn 'Aqnin's text are in order.

The above analysis of ibn 'Aqnin's retelling is based upon Ms. JTS Lutzki 1056. However, as noted above, the Patriarch's tradition presented therein is based upon Ms. Oxford Poc. 189. This change is because the JTS manuscript reads a bit differently: משחא דרישא לא עדי רישה (mšḥa d-ryš‘a la 'ady ryšh, "head oil will not pass over his head"). Halkin (1964, 494-495) noted this in his critical apparatus but did not discuss its implications in his notes. Aaron Greenbaum $(1978,317)$ pointed to this variant reading, whose tradition is strikingly similar to that of the Masoretic one (on two points). Should this reading of the Patriarch's Syriac tradition prove authentic (casting doubt as to the provenance of the other version), it carries with it implications for Syriac and Christian Studies as well as our knowledge of the Baghdadi tradition of the Peshitta text. Michael Perry Weitzman has argued that preference be given to Peshitta manuscript Florence, Laurentian Library, Or. 58, or "9a1", whose unique readings are similar to the Masoretic tradition (1985, 225-258). In our verse, the Laurentine manuscript reads:

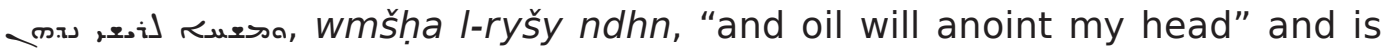
indeed quite similar to the Masoretic text "head oil will not quit my head". Ignacio Carbajosa (2008, 263-268) has convincingly argued that this reading is the original Syriac tradition, with all other manuscripts (even possible earlier ones) being merely emended texts based upon the Septuagint (LXX) tradition ("oil of the wicked shall not...", see above). The JTS manuscript's reading could then further strengthen Carbajosa's 
argument, as this tradition was apparently known by the Patriarch in eleventh-century Baghdad.

\section{The Christian Affinities within R. Hayya's Textual Heritage}

It is thus fascinating to see that R. Hayya Ga'on quotes the Syriac tradition to this verse in his Kitāb al-Hāwī ("The Compendium"), a dictionary encompassing diverse Jewish material (Maman 2000, 344-345). R. Hayya's dictionary, sometimes translated as "The Comprehensive Book", is written in Judeo-Arabic with citations in Hebrew and Aramaic. The citations included in the entries run the gamut of Biblical and Rabbinic literature, with some entries defining words found in Jewish Babylonian Aramaic (an eastern dialect of Aramaic employed in Jewish texts). Following an approach popular with contemporary Arabic lexicographers, the work follows an anagrammatic system. Entries are arranged alphabetically; each heading consisting of a two- or three-letter word under which are grouped all extant roots obtained by permutation of the heading's letters (Brody 1998, 330331; Maman 1999).

In an unpublished Genizah fragment (Cambridge University Library, L-G Add. 2) of this work we find that R. Hayya Ga'on made use of his knowledge of the Syriac tradition to this verse to elaborate upon the root $d h n$, (n. "oil", v. "to oil", "to anoint"). He writes thus: נקל אלי אלסריאניה שמן ראש אל יניא ראשי ימשחן דרשיעא לא ידהן, nql 'aly al-sryānyah šemen roš 'al yani roši ymšḥan d-ryšy'a la ydhn, as copied in Syriac "head oil will not quit my head", "oil of the wicked will not anoint [me]".

Leaving aside previous anecdotal evidence (at the very best secondhand; R. Mașliaḥ's account of R. Hayya's actions), we now face firsthand 
literary evidence of R. Hayya Ga'on's knowledge of the Syriac tradition to our verse. It would seem that R. Mașliah's mission bore fruit; the tradition with which he returned was incorporated within his master's encyclopedic work. However, when comparing the quote in R. Hayya Ga'on's Compendium to the one in ibn 'Aqnin's account, a few differences become apparent. In the Compendium, the Syriac quote is mšhan d-rišy'a la ydhn, almost identical to the common Peshitta tradition (see above). As is to be expected, the quote calls the oil "oil of the wicked", thus sharing an affinity with the abovequoted Oxford manuscript (Ms. Oxford Pocock 189). On the other hand, the quote uses the verb ydhn (ndhn), as per the Peshitta, and not la 'ady, as in ibn 'Aqnin's account, in either the JTS (Lutzki 1056) or Oxford manuscripts.

This external evidence clearly witnesses R. Hayya Ga'on's use of his knowledge of a Syriac tradition and seems to cast doubt upon the reading in the above-quoted ibn 'Aqnin's text (Ms. JTS Rab. 1056, which is most possibly a scribal emendation influenced by the Masoretic text and unlikely an omission of the ayin with a transposition of the yod), while reinforcing our knowledge of the Baghdadi Syriac tradition. What remains unclear is whether R. Hayya is quoting the Peshitta firsthand (and not the Patriarch), or whether this is the Patriarch's response and R. Mașliah's account is skewed.

More curious is R. Hayya Ga'on's syntax in this fragment of his Compendium; he first writes that $d h n$ is the same in "Nabatean" (hu 'ayda' fi l-Nabațiya, הו איצ'א פי אל נבטיה) and then offers the Psalms translation as 'אלסריאניה' (al-Suryāniyya). As this translation is the Peshitta tradition and in juxtaposition to “Nabatean”, R. Hayya Ga’on's Judeo-Arabic 'אלסריאניה' (al-Suryāniyya) should be read as "Syriac" (Maman 2000, 353-354). However, in Judeo-Arabic this term almost always means "Aramaic", either Biblical or Talmudic (Blau 2006, 295). The question then poses itself whether R. Hayya Gaon viewed the Syriac tradition as on par with Jewish 
Targumim (Aramaic translations) and called it similarly. Or did he perhaps call the Peshitta by its rightful name, i.e. the "Syriac" tradition? Indeed, R. Hayya Ga'on was fully aware that "Syriac" was the name of the language and script used by Christians in Iraq; he mentions this clearly in a response written to Kairouan no later than 1004 (Harkavy 1887, 230 no. 437). Further research of R. Hayya Ga'on's writings may shed more light on this question and upon R. Hayya Ga'on's appreciation for the Syriac tradition. What can be said with certainty is that R. Hayya Ga'on made use of a foreign tradition, one that contradicts the Masoretic one on several counts, and despite this did not make any mention of the obvious discrepancies between the texts.

Besides the fascinating discovery that R. Hayya Ga'on quotes the Syriac tradition as a proof-text in his work, and a newer appreciation for his doing so despite the differences in traditions, we are also privy to a further point of analysis: the dating of his Kitāb al-Hāwī. It seems reasonable that $\mathrm{R}$. Hayya Ga'on first became aware of this Syriac tradition to this verse only when this episode transpired. Had the reverse been the case, the Ga'on's word, or work, should have been the deciding factor in the Yeshiva's debate, as we have seen previously in another debate. Thus we can postdate this text to that of our debate, using this anecdote to add to our knowledge of Gaonic literary activities.

It bears noting that our verse is cited in a lexicographic function in an additional entry in R. Hayya Ga'on's aforementioned Compendium. In his commentary to Numbers (Kitāb al-Tarjiyḥa, Book of Arbitration), R. Judah ibn Bal'am (1000-1070) quotes R. Hayya Ga'on's aforementioned Kitāb alHāwī as defining the word yani as "to prevent" or "to cease" (exactly as did R. Sa'adyah Ga'on and his student Dunaš; see above) and juxtaposes this word to other Hebrew words of a similar "root" (Perez 1970, 90). It goes without saying that in this entry, the Syriac tradition is not mentioned at 
all, as it has, again, substituted a different verb (dhn, "annoint" or as in ibn 'Aqnin la 'ady, "will not pass") for the verb in question.

However, this bibliographic evidence towards dating Kitāb al-Hāwī is also not absolute; as mentioned above, R. Mașliaḥ related a similar incident where R. Hayya Ga'on weighed in on an exegetical debate, also in Psalms, by using a draft-copy (masūda in Judeo-Arabic) of his Compendium as a proof-text. Hence, at least part of the work was already in written form at the time of R. Mașliah's stay, and therefore our episode's input on the text is a later addition (perhaps localized to this entry alone).

In parallel to the paucity of data mentioned previously, so too are we not privy to the date of this event and thus in the dark as to which Patriarch was approached. Based upon correspondence between R. Mașliaḥ and R. Hayya Ga'on, we could suggest a terminus ad quo of 1004 (when R. Hayya assumed the Gaonate, leadership of the Academy), more reasonably not before 1010, and a terminus ad quem of 1021. This date is based upon an halakhic responsum R. Mașliah received from R. Hayya Ga'on in 1022 (Ben Sasson 1991, 139), most likely after R. Maṣliaḥ's return home from his studies. Should this conjectured date be accurate, our incident took place well within the period when, according to Aubrey Vine $(1937,138)$, Mar Yuhanna VI bar Nazuk (1013-1020) held office (Baum 2003, 172 dates Mar Yuhanna 1012-1016).

However, the 1021 date proposed is itself not absolutely certain and we must consider the possibility of a later date, being certain only that the latest date could be April 1038, when R. Hayya Ga'on passed away. This allows for two additional possibilities, either Mar Isho'yahb IV (1021-1025) or Elias I (1028-1049) (Vine 1937, 138; Baum, 2003, 172). Since ecclesiastic history on the Patriarchs of this era is scanty, any further investigation and attempt to accurately date our episode will add a valuable facet to our knowledge of the Church of the East and its Patriarch's relationship 
with the leader of the Baghdadi Jewish community (and the Mediterranean Diaspora).

\section{A Note on Languages and Scholarly Communication}

A further point of inquiry into the episode, not taken into account by previous literature, bears noting. Extant sources suggest that at the time of our account, the fluency of the common Christian in Syriac had largely diminished in favor of Arabic (Vollandt 2015, 33). It may be suggested that with it, the ability to read Estrangela (classical Syriac script) had also declined. Perhaps R. Hayya Ga'on trusted only the Patriarch to provide an accurate reading, or perhaps the texts in need were only available to the Patriarch and not to the lay individual. In this case, R. Hayya Ga'on's seeming reliance upon the Patriarch must be tempered (contra earlier studies, see above); the authority for the tradition lies not with the Patriarch but with the text in his care. Should this indeed be the case, we have again seemingly uncovered a hint towards R. Hayya Ga'on's appreciation for the Syriac tradition, the Peshitta (perhaps based upon the various Syriac traditions which attribute to it a Jewish provenance), an appreciation which to date has yet to be systematically explored. It may be suggested that given the various traditions for the origins of the Peshitta, which base themselves largely upon a Jewish source (Dirksen 1988, 255), it is not impossible that R. Hayya Ga'on, too, saw this Aramaic Targum as an originally Jewish one, and not necessarily representative exclusively of the Christian tradition.

More curious is the fact that of all the members in the Academy present during the debate, R. Hayya Ga'on chose the foreign student as his emissary and not a local one. Arguably, ample Yeshiva and Beit Din 
(legal court) officers were at R. Hayya Ga'on's disposal and could equally have served as messenger, not to mention sending a local student. While the choice was very likely a didactic one, exposing the new student to the internal workings of the Academy as well as Jewish-Baghdadi society, a formal issue presents itself. Ostensibly, R. Mașliaḥ spoke a different dialect of Arabic (Western or Maghrebi, if not Siculo-Arabic; Agius 2010, 111112; Metcalfe 2011) than the local Baghdadi one. Thus his appointment as messenger might propose that the two leaders, R. Hayya Ga'on and the Patriarch, shared a familiarity which dispensed with formalities such as a possible language barrier or a sense of slight at being queried by a foreigner. This familiarity between the two dignitaries suggests a much closer tie than previously assumed.

It is however, not entirely impossible that R. Maṣliaḥ, as a seasoned traveler and scholar-merchant, was fluent in other dialects as well. On the other hand, Ronny Volandt $(2015,31)$ notes that many Patriarchs had an inadequate knowledge of Arabic and it is highly possible that the Patriarch in our account had a poor command of the language. Thus, even in the event that R. Mașliah was fluent in Baghdadi Arabic, we cannot rule out that the Patriarch was not (preferring Syriac), and a language barrier might still have existed. This possibility of a language barrier between messenger and addressee (and the disregard for such) serves to strengthen our proposal of a hitherto explored familiarity between the two dignitaries; R. Hayya Ga'on's relationship with his Christian counterpart was such that he felt no compunction in sending his query with a foreign student instead of a local. 


\section{The Cultural Backgrounds of Jews in Baghdad as Opposed to Sicily}

The next point in our analysis of this account is R. Mașliah's reaction to his master's mission. Interestingly, the literature dealing with the episode has placed little or no emphasis upon R. Mașliah's home culture, and certainly not in juxtaposition to the cultural setting enjoyed by the Yeshiva in Baghdad.

David Sklare (1996, 99-101) follows Joel Kraemer (1986) in characterizing the period during the tenth and first half of the eleventh centuries as one of "renaissance" in Islam. At the time, Baghdad had become a center for the study and translation of Greek philosophical and scientific works. Scholars, scribes, teachers, booksellers, and merchants formed a humanistic culture featuring a love for mankind or humanness, along with conceptions of common kinship and the unity of mankind. The prevailing humanistic atmosphere in cosmopolitan Baghdad allowed for (and oftentimes outright encouraged) interaction between faiths, contacts which oftentimes developed into friendships.

Public contacts of this sort were mainly found at majālis (sing. majlis), meetings in which scholars and other intellectuals gathered to discuss topics of mutual interest (Sklare 1996, 100). Meetings were conducted in settings like bookstores, shops, markets, and even bathhouses (Kraemer 1986, 57). Many of the bookstores were located in the Tāq al-Harrāni (the Harrani Archway), which bordered on the Al-Ațiqa Quarter where a large Jewish community was situated (Kraemer 1986, 57, 78). The Pumbadithan Academy transferred to Baghdad at the close of the ninth century (circa 890) with its sister Academy, Sura, moving there approximately a century later (circa 987; Sklare 1996 71-72; Brody 1998, 36). Importantly for our discussion, R. Sherira Ga'on's court was located in the Al-'Ațiqa Quarter 
(Sklare 1998, 72). There is no indication that R. Sherira's son, R. Hayya, had relocated in the years between his father's reign and his own, and it is fairly safe to assume R. Hayya presided over his court at the same location.

Other, more formal sessions, which were usually for the purpose of debate, were held at the courts of local officials (Kramer 1986, 58; Sklare 1996, 100-101). Although most of the evidence of Jewish participation in formal, debate-oriented majālis provided by the above sources is from the tenth century, the zeitgeist was such that it is reasonable to assume that such contacts continued even during the first half of the eleventh century, when our episode transpired, especially in light of the close proximity between the nexus of humanistic meetings in the many bookstores in the Harrani Archway and the Al-'Ațiqa Quarter where R. Hayya resided.

Thus our surprise should not necessarily be focused upon R. Hayya Ga'on's willingness to request a Scriptural translation from a member of another faith; considering the humanistic culture permeating Baghdad for over a century, this is almost to be expected. In fact, R. Hayya Ga'on made use of non-Jewish literature in his responsa and commentaries (Halkin 1975, 227; Brody 1999, 299; Sklare 1996, 52, 74) as well as in his Compendium and was not remiss from inquiring lexical information from others (as he himself stated in his defense of sending R. Mașliah to the Patriarch; Maman 2000, 368-369).

Rather, we propose that the focus of inquiry should be upon R. Mașliaḥ's account to the Nagid of his own indignation. It seems fairly safe to assume from this display that relations between Jews and Christians in eleventhcentury Sicily were in no way as open as in Baghdad. This may have been due to a predominately Eastern Orthodox (Byzantine) Christian population, the proximity to Roman Catholic Italy, a different cultural milieu, or a combination of these factors (Simonsohn 2011, 12-15). What is clear is that 
what can be expected of a Baghdadi Jew living in a 'cosmopolitan' cultural setting is not to be assumed of a Sicilian Jew.

\section{The Textual History of Debates on Non-Jewish Scholarship}

The final point in our analysis of the account is R. Mașliah's account of R. Hayya Ga'on's rather lengthy rebuke. The account is a quote from the Nagid's dictionary, originating from a missive containing a biography of R. Hayya sent by R. Mașliah to the Nagid. Despite the Hagid's dictionary having been lost, its appearance in booklists found in the Cairo Genizah (Allony 2006, 31, 257, 265, 287-8) testifies to its popularity. While we have noted minor edits by ibn 'Aqnin, it is safe to assume he would not have made major changes in so popular a text.

R. Hayya Ga'on offers various and, upon careful examination, apparently independent reasons: 1 ) his predecessors and forefathers had done so; 2) the queries were limited to philological and exegetical ones; 3) such queries could also even be posed to the lowest strata of society; and 4) "as is well known and has been passed down" (seemingly in addition to invoking his forebears). The following careful analysis of the above leads us to the conclusion that R. Hayya Ga'on offered several rationales for this praxis more in order to calm his student than as his own reasoning.

Each reason offered possesses stand-alone value. As a jurist and a Halakhic authority, R. Hayya Ga'on was wont to enlist his forbearers' opinions and stances in his Talmud commentaries and Responsa, relying upon them whole-heartedly (Dubovick 2015, 222-223). Testimony of their actions alone should have served as reason enough for R. Hayya Ga'on. The mention of a limitation to lexicographic and philological queries seems 
almost extraneous within the Yeshiva setting, almost as if this limitation could serve in itself as reason enough to permit querying members of another faith. Despite the Halakhic repercussions such lexical inquiries might bear, the limit posted by R. Hayya Ga'on implies a prohibition of (or at least an aversion to) inquiry regarding theological questions, thus placing a damper on the issue; the topic is merely a benign one and therefore one may ask such questions, even though questions in other areas were to be seen as taboo.

In the same fashion, one wonders at the third statement; the permissibility to query members of other faiths is not limited to those knowledgeable but permitted even of those in the lowest strata of society. R. Hayya Ga'on, Talmudist first and foremost, almost assuredly had in mind the Rabbinic appraisal of these two professions, shepherds and cow-hands; throughout the Talmudic literature they are held almost in utter infamy. Thus we find remarks such as (Tosefta Bava Metzia 2:33, ${ }^{4}$ parallels in Babylonian Talmud Avodah Zarah 13b, ${ }^{5} 26 a$ and Sanhedrin 57a $)$ : “Gentiles, shepherds and their breeders are not raised [from a pit, i.e. assisted] nor lowered [i.e. endangered]"; R. Dosa ben Hyrcanus' belittlement of R. Akivah, "You have not yet achieved [the status] of a cowhand" along with R. Akivah's humble concurrence, "not even that of a shepherd"7 (Babylonian Talmud Yevamoth 16a, similarly R. Yohanan's retort in Babylonian Talmud Sanhedrin $\left.26 a^{8}\right)$; the Mishnah's choice as the epitome of non-Jurist material

Ed. Lieberman 2001, 72: "הגוים והרועים בהמה דקה ומגדליה לא מעלין ולא מורידין המינין והמשומדין "והמסורות מורידין".

5 Ms. Paris, Bibliothèque nationale de France, Suppl. Heb. 1337: הגוים והרועים בהמה דקה לא

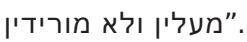

6 Venice print 1520-1523: "והתניא גוים ורועי בהמה דקה לא מעלין ולא מורידין".

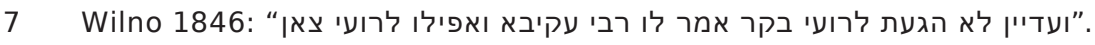

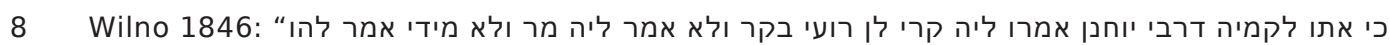
"ואי קרי לכו רועי צאן מאי אמינא ליה ". Compare Cambridge University Library, Genizah Fragment 
"I accept three cowhands [as Judges]" (Mishnah Sanhedrin 3:2) ${ }^{9}$ through the Talmud's outright negation of livestock-herders as Judges (Babylonian Talmud Sanhedrin 25b). ${ }^{10}$ In other words, questions of this sort are almost to be considered so trivial as to be non-influential, that whoever may provide an answer may then be taken seriously. This view, then, is not necessarily dependent upon R. Hayya Ga'on's forebears having done so, but rather upon a line of reasoning grounded in the Halakhic world.

Finally, R. Hayya Ga'on informs his student that this praxis is a wellknown one, knowledge of it being passed down publicly from generation to generation, and not necessarily a Geonic family tradition to which $\mathrm{R}$. Hayya Ga'on alone was privy. In the first argument of his rebuke, R. Hayya Ga'on takes into account his student's foreign background and ignorance of common Baghdadi custom. In this final phase he rebukes him for his ignorance of a supposedly well-known practice not limited to the Geonic hierarchy.

Contrarily, it is quite telling that in his rebuke R. Hayya Ga'on made no mention of Talmudic dictums involving gleaning information from members of other faiths, such as R. Yoḥanan's comment "anyone who speaks wisdom, even from among the Nations, is hailed as "wise one'" (Babylonian Talmud Megillah 16a), ${ }^{11}$ as proof of his custom. R. Mașliah was an accomplished Torah scholar and ought to have readily accepted a Talmud quote as basis for the practice.

This abundance of ratios would seem to point to a more protracted debate between Master and student than otherwise displayed in the

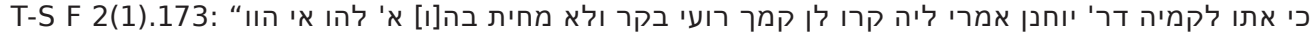

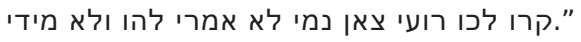

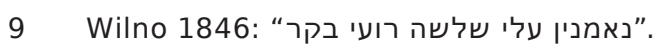

"אמר רבא רועה שאמרו אחד רועה בהמה דקה ואחד רועה בהמה גסה" 10.

"אמר רבי יוחנן כל האומר דבר חכמה אפיל באומות העולם נקרא חכם" 11.
} 
text before us (perhaps R. Mașliah having truncated the discussion in his presentation to the Nagid). Perhaps R. Hayya Ga'on's acceptance of his forebears' practice was not equally appreciated by R. Mașliah, whose allegiances might not necessarily lie completely with the Babylonian Academies. This might explain a need for R. Hayya Ga'on's limitation of the praxis to 'mere' lexical issues. By adding the further clarification of "shepherds and cowhands", the issue of approaching a foreign cleric has thus been effectively defused, seemingly added to allay any doubts left in the rebuked student's mind. By proclaiming the practice to be well-known among the populace, in one statement R. Hayya Ga'on sealed the case for Babylonian primacy in Halakhic rulings while simultaneously demoting the Mediterranean Diaspora, learned as it may have been to a secondary position, seeing them as "out of the loop".

\section{Conclusion}

In conclusion, a careful study of the individual factors in this wellknown incident, especially when viewed within a broader perspective of different cultures, sheds new light upon several facets of Jewish-Christian relationships, both in Baghdad as well as (inadvertently) in Sicily.

Thus, while R. Mașliah is a fellow Jew and a Talmud scholar in his own right, in his own account he presents himself as uninformed regarding the intricate relations between the Jewish scholars in Baghdad and their Christian counterparts. R. Hayya Ga'on rebukes him for his reluctance to consult the Christian Patriarch, all the while reassuring him of Jewish autonomy in the issue with the argument that on some matters Jews may without qualm consult even livestock-herders (let alone a non-Jewish scholar and religious authority). The incident impressed R. Mașliaḥ enough 
to include it in his biography of R. Hayya Ga'on, thereby preserving the messages transmitted for posterity.

The incident is also significant for the history of Jewish-Christian textual exchange, as portrayed by the textual analysis of the various translations and commentaries in Aramaic and Syriac related to the Psalms verse in question. Therefore, the close reading of the anecdote adds to our knowledge of the Eastern Patriarchy in the eleventh century while posing new venues for research in these fields.

\section{Acknowledgments}

A preliminary version of this article was delivered as a paper read at Eastern Jews and Christians in Interaction and Exchange in the Islamic World and Beyond: A Comparative View, JCM Center, Open University, Ra'anana - BenZvi Institute, Jerusalem, June 22-23, 2016. I am grateful to the organizers of the workshop, Prof. Alexandra Cuffel and Dr. Ophira Gamliel, and to the participants for their feedback. In particular, Dr. Gamliel's comments and insights during the editing were most helpful and prevented several serious errors. I wish to thank the anonymous readers for their input in improving the quality of the paper. I am indebted to Prof. Mordechai Akiva Friedman, who graciously reviewed and edited the Judeo-Arabic text translated herein. His comments and corrections have enhanced and in several cases changed the direction of this paper. Prof. Robert Brody, Dr. James Nathan Ford, and Dr. Pinchas Roth contributed to many facets of the paper. Needless to say, all responsibility lies fully with the author. 


\section{Reference List}

Agius, Dionisius A. 2010 (1996). Siculo Arabic. London and New York: Routledge.

Allony, Nehemiah. 2006. The Jewish Library in the Middle Ages. Jerusalem: Ben-Zvi Institute for the Study of Jewish Communities in the East.

Baum, Wilhem, and Dietmar W. Winkler. 2003. The Church of the East: A Concise History. London and New York: Routledge Curzon.

Ben-Sasson, Menahem. 1991. The Jews of Sicily: 825-1068, Documents and Sources [in Hebrew], Oriens Judaicus, series I, volume I. Jerusalem: Ben-Zvi Institute.

Berlin, Adele, and Marc Zvi Brettler, eds. 2004. The Jewish Study Bible. Oxford: Oxford University Press.

Blau, Joshua. 2006. A Dictionary of Mediaeval Judaeo-Arabic Texts. Jerusalem: The Academy of the Hebrew Language, The Israel Academy of Sciences and Humanities.

Brody, Robert. 1998. The Geonim of Babylonia and the Shaping of Medieval Jewish Culture. New Haven and London: Yale University Press.

_-_. 1999. "Zoroastrian Themes in Geonic Responsa." Irano-Judaica IV: $179-186$.

Carbajosa, Ignacio 2008. The Character of the Syriac Version of Psalms. Leiden: Brill.

Dirksen, Peter B. 1988. “The Old Testament Peshitta." In Mikra: Text, Translation, Reading and Interpretation of the Hebrew Bible in Ancient Judaism and Early Christianity, edited by M.J. Mulder, 255-297. Assen: Van Gorcum; Philadelphia: Fortress Press. 
Dubovick, Yosaif Mordechai. 2015. “Rabbenu Hananel and the Geonim of Babylonia: Rabbenu Hananel's Commentarial and Legal Methodology." [in Hebrew] PhD Dissertation, Bar-Ilan University, Ramat Gan.

Eldar, Ilan. 2014. Hebrew Language Study in Medieval Spain. Jerusalem: The Academy of the Hebrew Language.

Filipowski, Herschell, ed. 1854. The First Hebrew and Chaldaic Lexicon to the Old Testament, by Menahem ben Saruk. London: The Hebrew Antiquarian Society.

- - 1855. Criticae Vocum Recensiones Donasch ben Librat [in Hebrew]. London: The Hebrew Antiquarian Society.

Gil, Moshe. 2004. Jews in Islamic Countries, translated by D. Strasser, 590-593. Leiden-Boston: Brill.

Greenbaum, Aaron, ed. 1978. The Biblical Commentary of Rav Samuel Ben Hofni Ga'on [in Hebrew]. Jerusalem: Harav Kook Institute.

Halkin, Abraham S., ed. 1964. Josephi b. Judah b. Jacob ibn 'Aknin, Divulgatio Mysterium Luminumque Apparentia [in Hebrew]. Jerusalem: Mekize Nirdamim.

- - Moshe ben Ya'akovibn Ezra, LiberDiscussioniset Commemorationis (Poetica Hebraica) [in Hebrew]. Jerusalem: Mekize Nirdamim.

Harkavy, Albert. 1970. Hadashim Gam Yeshanim. Jerusalem: Carmiel. Harkavy, Albert, ed. 1887. Zikkaron Larishonim Vegam Laahronim: Studien und Mittheilungen aus der Kaiserlichen Offentlichen Bibliotek zu St. Petersberg: vierter theil. Berlin: H. Itzkowski.

JPS. 1985. Tanakh, A New Translation of THE HOLY SCRIPTURES According to the Traditional Hebrew Text. Philadelphia: The Jewish Publication Society. 
Kafih, Yosef, ed. 1966. Tehillim im Targum v'Pirush HaGaon Rebbenu Saadyah ben Yosef Fiyyumi. Jerusalem: American Academy for Jewish Research.

Kraemer, Joel. 1986. Humanism in the Renaissance of Islam: the Cultural Revival during the Buyid Age. Leiden: Brill.

Leonhard, Clemens. 2001. Ishodad of Merw's Exegesis of the Psalms 119 and 139-147. Leuven: Peeters.

Maman, Aharon. 1999. "The Lexicographical Method of R. Hai Ga'on in Kitab al-Hawi." [in Hebrew] In Studies in Ancient and Modern Hebrew, Presented to M.Z. Kedarry, edited by S. Sharvit, 235250. Ramat-Gan: Bar-Ilan University Press.

_- - 2000. “The Remnants of R. Hai Ga'on's Dictionary 'Kitāb alHāwi' in the Adler and Taylor-Schechter Geniza Collections." [in Hebrew] Tarbiz 69: 341-421.

Metcalfe, Alex. 2011. "Sicily." In: Encyclopedia of Arabic Language and Linguistics, edited by Lutz Edzard, and Rudolf de Jong. Brill. $<$ http://dx.doi.org.proxy1.athensams.net/10.1163/1570-6699_ eall_EALL_SIM_0122>.

Perez, Maravi. 1970. “Commentary on Numbers \& Deuteronomy: (from 'Kitab Altargih') by Jehuda b. Shmuel Ibn Bal'am.” [in Hebrew] Master's Thesis, Bar-Ilan University, Ramat Gan.

Simonsohn, Shlomo. 2011. Between Scylla and Charybdis: The Jews in Sicily. Leiden: Brill.

Sklare, David. 1996. Samuel Ben Hofni Gaon and His Cultural World: Texts and Studies. Leiden: Brill.

Skoss, S.L., ed. 1936. The Hebrew-Arabic Dictionary of the Bible known as Kitab Jami al-Alfaz (Agron) of David Ben Abraham al-Fasi, vol. I. New Haven: Yale University Press. 
- - 1945. The Hebrew-Arabic Dictionary of the Bible known as Kitab Jami al-Alfaz (Agron) of David Ben Abraham al-Fasi, vol. II. New Haven: Yale University Press.

Stec, David M. 2004. The Targum of Psalms. London: T\&T Clark.

Steinschneider, Moritz. 1855. Ersch and Gruber's Allgemeine Encyclopädie der Wissenschaften und Künste, Leipzig, II, 31, 56.

Stern, Salomo Gottlieb. 1870. Liber Responsionum [in Hebrew]. Wien.

Vine, Aubrey R. 1937. The Nestorian Churches. London: Independent Press.

Vollandt, Ronny. 2015. Arabic Versions of the Pentateuch: A Comparative Study of Jewish, Christian, and Muslim Sources. Leiden: Brill.

Weitzman, Michael Perry. 1985. "The Originality of Unique Readings in Peshitta MS 9a1." In The Peshitta: Its Early Text and History. Papers Read at the Peshitta Symposium Held at Leiden 30-31 August 1985, edited by P.B. Dirksen, and MJ Mulder (MPIL 4), 225258. Leiden: Brill.

- - - 1999. From Judaism to Christianity: Studies in the Hebrew and Syriac Bibles. Oxford: Oxford University Press. 